\title{
Cloning and characterization of the NapA acid phosphatase/phosphotransferase of Morganella morganii: identification of a new family of bacterial acid-phosphatase-encoding genes
}

\author{
Maria Cristina Thaller, ${ }^{1}$ Giovanna Lombardi, ${ }^{2}$ Francesca Berlutti, ${ }^{1}$ \\ Serena Schippa, ${ }^{1}$ and Gian Maria Rossolini ${ }^{2}$
}

Author for correspondence: G. M. Rossolini. Tel: +39577 280903. Fax: +3957742011.

1 Istituto di Microbiologia, Università 'La Sapienza', Piazzale A. Moro, 5, 00185 - Rome, Italy

2 Dipartimento di Biologia Molecolare - Sezione di Microbiologia, Università di Siena, Via Laterina, 8 , 53100 - Siena, Italy

\begin{abstract}
The gene encoding a minor phosphate-irrepressible acid phosphatase (named NapA) of Morganella morganii was cloned and sequenced, and its product characterized. NapA is a secreted acid phosphatase composed of four $27 \mathrm{kDa}$ polypeptide subunits. The enzyme is active on several organic phosphate monoesters but not on diesters, and is also endowed with transphosphorylating activity from organic phosphoric acid esters to nucleosides and other compounds with free hydroxyl groups. Its activity is inhibited by EDTA, inorganic phosphate, nucleosides and $\mathrm{Ca}^{2+}$, but not by fluoride or tartrate, and is enhanced by $\mathrm{Mg}^{2+}, \mathrm{Co}^{2+}$ and $\mathrm{Zn}^{2+}$. At the sequence level, the NapA enzyme did not show similarities to any other sequenced bacterial phosphatases. However, a search for homologous genes in sequence databases allowed identification of two open reading frames located within sequenced regions of the Escherichia coli and Proteus mirabilis genomes respectively, encoding proteins of unknown function which are highly homologous to the Morganella enzyme. Moreover, the properties of the NapA enzyme are very similar to those reported for the periplasmic nonspecific acid phosphatase II of Salmonella typhimurium (for which no sequence data are available). These data point to the existence of a new family of bacterial acid phosphatases, which we propose designating class B bacterial acid phosphatases.
\end{abstract}

Keywords: Morganella morganii, NapA, acid phosphatase/phosphotransferase

\section{INTRODUCTION}

Enzymic cleavage of phosphoester bonds is a fundamental step in many biochemical pathways and several phosphatases, different in structure and function are typically present in the prokaryotic cell (Beacham, 1979; Dvorak $e t$ al., 1967; Uerkvitz \& Beck, 1981). However, even in Escherichia coli, which is the best studied model of such cells, the exact number of phosphatases as well as the role(s) of some of them remain to be defined. The picture is further complicated by the fact that different patterns of

Abbreviations: G2P, glycerol 2-phosphate; PDP, phenolphthalein diphosphate; pNP, p-nitrophenol; pNPP, p-nitrophenyl phosphate.

The GenBank/EMBL accession number for the nucleotide sequence reported in this paper is $X 78328$. phosphatase activities are found in different bacterial species, even those belonging to closely related taxa, as observed for members of the family Enterobacteriaceae (Cocks \& Wilson, 1972; Edwards et al., 1993; Groisman et al., 1992; Pompei et al., 1990, 1993).

Characterization of the different phosphatases present in enteric bacteria is, therefore, interesting not only in relation to microbial physiology and enzymology but also enterobacterial taxonomy and phylogenesis.

In a previous investigation on the phosphatases produced by Morganella morganii, which is one of the few enterobacterial species able to produce a high-level phosphateirrepressible acid phosphatase activity (HPAP phenotype) (Pompei et al., 1990, 1993), we found that Morganella produces two different phosphate-irrepressible acid phos- 
phatases active on $p$-nitrophenyl phosphate ( $p$ NPP), and that the major one, named $\mathrm{PhoC}$, is apparently associated with the HPAP phenotype (Thaller et al., 1994). PhoC is a nonspecific acid phosphatase homologous to other bacterial acid phosphatases, including the PhoN enzymes of Salmonella typhimurium and Providencia stuartii, and the PhoC enzyme of Zymomonas mobilis, and we proposed designating this family of enzymes class A bacterial acid phosphatases (Thaller et al., 1994).

In the present work we have studied the minor phosphateirrepressible acid phosphatase produced by $M$. morganii, named NapA, and found that it belongs to another family of nonspecific acid phosphatases which could be widespread among the Enterobacteriaceae and which we propose designating class $\mathrm{B}$ bacterial acid phosphatases.

\section{METHODS}

Bacterial strains and genetic vectors. The $M$. morganii $\mathrm{RS} 12$ strain used for library construction has been previously described (Thaller et al., 1994). M. morganii ATCC $25830^{\mathrm{T}}$ was also used as a reference strain. E. coli $\mathrm{DH} 5 \alpha$ (Sambrook et al., 1989) was used as the host for genetic vectors and recombinant plasmids. The Bluescript SK plasmid (Stratagene) was the vector used for the construction of the $M$. morganii genomic library and for subcloning procedures.

Recombinant DNA methodology. Basic recombinant DNA techniques were essentially as described by Sambrook et al. (1989). The procedure for construction of the Morganella genomic library has been previously described (Thaller et al., 1994). All sequences were determined on denatured doublestranded DNA templates by the dideoxy chain-termination method (Sanger et al., 1977). The nucleotide sequence was determined for both strands. Analysis and comparison of nucleotide and amino acid sequences were performed using the UWGCG software (release 7.3) (Devereux et al., 1984).

Phosphatase assays. The phosphatase activity of whole-cell or periplasmic protein preparations toward $p$ NPP was assayed by measuring the released $p$-nitrophenol $(p \mathrm{NP})$ at $414.5 \mathrm{~nm}$ and $\mathrm{pH}$ 12. The concentration of $p$ NPP in the assay was $5 \mathrm{mM}$. All assays were performed in a volume of $1 \mathrm{ml}$ and were initiated by addition of the substrate. Incubation was at $37^{\circ} \mathrm{C}$ for $20 \mathrm{~min}$. One unit of enzyme activity was defined as the amount of enzyme able to release $1 \mu \mathrm{mol} \not \mathrm{NP} \mathrm{min}^{-1}$ under the assay conditions.

For preparation of whole-cell proteins, bacteria were washed twice in normal saline, suspended in normal saline at an $\mathrm{OD}_{600}$ of 10 , and disrupted by sonication. Cell debris was then removed by centrifugation $\left(10000 \mathrm{~g}\right.$ for $10 \mathrm{~min}$ at $4^{\circ} \mathrm{C}$ ). Extraction of periplasmic proteins from $E$. coli was performed by chloroform treatment (Ferro-Luzzi Ames et al., 1984).

Determination of the $\mathrm{pH}$ optimum of the purified NapA enzyme was performed using $p$ NPP as substrate in $100 \mathrm{mM}$ buffers, including sodium acetate buffer $(\mathrm{pH} 4-6)$, Tris/ $\mathrm{HCl}$ buffer ( $\mathrm{pH} 7-9$ ), and glycine/ $\mathrm{NaOH}$ buffer ( $\mathrm{pH} \mathrm{10)}$. Measurement of enzyme activity in different buffer systems at overlapping $\mathrm{pH}$ values showed no significant buffer-related variation. Determination of the activity of the purified NapA protein using different substrates was performed as previously described (Kier et al., 1977; Weppelman et al., 1977) in $100 \mathrm{mM}$ sodium acetate buffer, pH 6. Inhibition assays were performed in the same buffer using $p$ NPP as the substrate. The enzyme was pre- incubated at $37^{\circ} \mathrm{C}$ for $30 \mathrm{~min}$ with each substance before starting the assay. Phosphotransferase activity was assayed in $100 \mathrm{mM}$ sodium acetate buffer, $\mathrm{pH} 6$, as previously described (Uerkvitz, 1988), using $p \mathrm{NPP}$ as the phosphate donor.

Protein determination. Protein concentration in solution was determined using a commercial kit (Bio-Rad Protein assay). BSA was used as the standard.

Protein electrophoretic techniques. SDS-PAGE was performed as described by Laemmli (1970). For detection of NapA enzyme activity after electrophoresis, the gel was incubated for $4 \mathrm{~h}$ at $37^{\circ} \mathrm{C}$ in several changes of renaturation buffer to obtain renaturation of the enzyme. Renaturation buffer was $100 \mathrm{mM}$ Tris/ $\mathrm{HCl}, \mathrm{pH} 7$, containing $5 \mathrm{mM} \mathrm{MgSO}_{4}$ and $1 \%(\mathrm{v} / \mathrm{v})$ Triton $\mathrm{X}-100$. After the renaturation treatment, the gel was equilibrated for $1 \mathrm{~h}$ in $100 \mathrm{mM}$ sodium acetate buffer, $\mathrm{pH} 6$, containing $5 \mathrm{mM} \mathrm{MgSO}_{4}$, and then developed for phosphatase activity. For development, the gel was incubated at $37^{\circ} \mathrm{C}$ for $30 \mathrm{~min}$ in the same buffer as used for equilibration with $5 \mathrm{mM}$ $p$ NPP added, washed in deionized water, and then incubated at $42{ }^{\circ} \mathrm{C}$ in a freshly prepared solution made by a $6: 1(\mathrm{v} / \mathrm{v})$ mixture of acidified ammonium molybdate $(4 \cdot 2 \mathrm{~g}$ ammonium molybdate $\mathrm{l}^{-1}$ and $28.6 \mathrm{ml}$ sulphuric acid $\mathrm{l}^{-1}$ ) and $10 \%(\mathrm{w} / \mathrm{v})$ ascorbic acid, to detect the presence of inorganic phosphate (Ames, 1966). Phosphatase activities were indicated by the presence of bluestained bands.

Purification of the NapA enzyme. When E. coli strains producing the Morganella NapA enzyme were grown in liquid medium at $37^{\circ} \mathrm{C}$, a consistent amount of the protein was released into the medium. The NapA protein was purified from the supernatant of a 24-h-old stationary-phase culture of clone PM9 (see below) grown at $37^{\circ} \mathrm{C}$ in Brain Heart Infusion broth supplemented with carbenicillin $\left(0.2 \mathrm{mg} \mathrm{ml}^{-1}\right)$. The culture supernatant was dialysed against $10 \mathrm{mM}$ Tris $/ \mathrm{HCl}, \mathrm{pH} 7 \cdot 4$, and loaded on a DEAE-Sepharose CL-6B (Pharmacia) column $(1.5 \times 11.5 \mathrm{~cm})$ equilibrated with the same buffer. The enzyme did not bind to the resin and eluted as a single peak. Fractions containing the eluted enzyme were collected, pooled, and dialysed against $10 \mathrm{mM}$ HEPES, $\mathrm{pH} 7 \cdot 4$. The enzyme was then loaded on a CM-Sephadex C-50 (Pharmacia) column $(1.5 \times$ $11.5 \mathrm{~cm}$ ) equilibrated with $10 \mathrm{mM}$ HEPES, pH 7.4. Again, the enzyme did not bind to the resin and eluted as a single peak. Fractions containing the eluted enzyme were pooled, dialysed against $100 \mathrm{mM}$ sodium acetate buffer, $\mathrm{pH} 6$, and concentrated by ultrafiltration in a Centricon 10 concentrator (Amicon). At this point the enzyme was $>95 \%$ pure, as assayed by SDSPAGE, and only two additional bands were evident. Removal of these contaminants was obtained by gel-filtration. For this purpose, SDS was added to a final concentration of $2 \%(\mathrm{w} / \mathrm{v})$ and the enzyme was immediately loaded (maximum loading volume $0.3 \mathrm{ml}$ ) onto a Sephacryl S-200 (Pharmacia) column $(1 \times 40 \mathrm{~cm})$ equilibrated with $100 \mathrm{mM}$ sodium acetate buffer, $\mathrm{pH}$ 6. The enzyme eluted as a single peak and the fractions containing it were pooled, dialysed against $100 \mathrm{mM}$ sodium acetate buffer, $\mathrm{pH} \mathrm{6}$, and concentrated by ultrafiltration as described above.

For determination of the molecular mass of the NapA protein by means of gel-filtration, the purified protein was applied to a Sephacryl S-200 column $(1 \times 40 \mathrm{~cm})$ equilibrated and eluted with $100 \mathrm{mM}$ sodium acetate buffer, $\mathrm{pH}$ 6. The Sephacryl S-200 column was calibrated with protein standards (Pharmacia) dissolved in elution buffer. The peak fraction of each protein was determined by $A_{280}$. A linear plot of the partition coefficients (Reiland, 1971) versus the logs of the molecular masses of the protein standards was used to estimate the molecular mass of the phosphatase. 
$\mathbf{N H}_{\mathbf{2}}$-terminal amino acid sequencing. The purified protein preparation was subjected to SDS-PAGE and transferred electrophoretically to a polyvinylidene difluoride membrane (Immobilon, Millipore). The transferred protein was stained with Coomassie brilliant blue R-250 and the band was excised and subjected to sequence analysis using an Applied Biosystems model 470A gas-phase sequencer (Matsudaira, 1987).

\section{RESULTS}

\section{Cloning of the $M$. morganii genetic determinant encoding the minor phosphate-irrepressible acid phosphatase (NapA)}

The $M$. morganii gene coding for the minor phosphateirrepressible acid phosphatase (named NapA) was isolated from a genomic library of $M$. morganii RS12, constructed in the plasmid vector Bluescript SK and transformed in $E$. coli $\mathrm{DH} 5 \alpha$ by the same shotgun cloning strategy previously used for isolation of the Morganella phoC gene (Thaller $e$ t al., 1994).

Using this strategy, two clones (PM2 and PM9) were identified, which showed acid phosphatase activity much higher than E. coli DH $5 \alpha$ (pBluescript) (data not shown) and produced an acid phosphatase composed of a $27 \mathrm{kDa}$ polypeptide which was not detectable in E. coli (Fig. 1a) and apparently corresponded to the minor phosphateirrepressible acid phosphatase detectable in Morganella by (a)

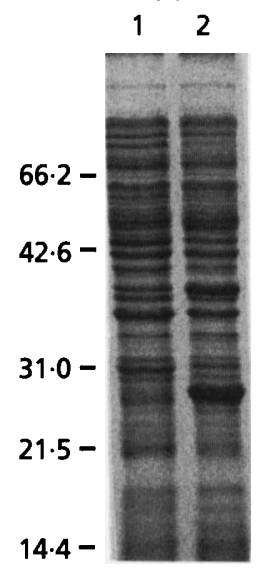

(b)

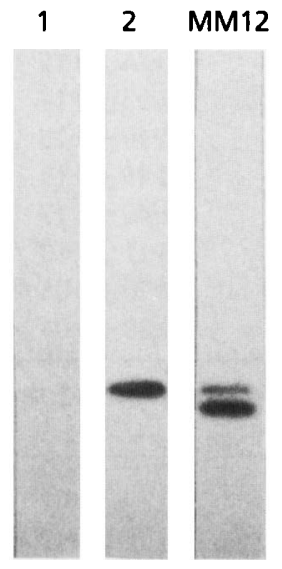

(c)

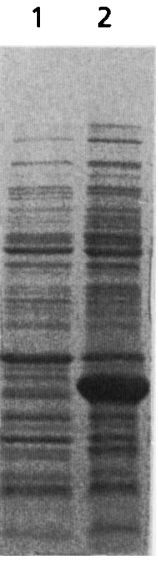

Fig. 1. SDS-PAGE analysis of proteins of $E$. coli PM9 and $E$. coli DH5 $\alpha$ (pBluescript). (a) Coomassie-blue-stained whole-cell proteins of $E$. coli DH5 $\alpha$ (pBluescript) (lane 1) and PM9 (lane 2); proteins were prepared from late stationary phase cells grown in terrific broth (Sambrook et al., 1989). (b) Same samples as in (a) but in this case a lower amount of protein was loaded and, after electrophoresis, the gel was subjected to renaturation treatment and developed for phosphatase activity at pH 6 as described in Methods; the lane labelled MM12 was loaded with a whole-cell protein preparation of $M$. morganii MM12, to show for comparison the two phosphate-irrepressible acid phosphatases that can be resolved in $M$. morganii by the same zymogram technique (Thaller et al., 1994). (c) Coomassie-bluestained periplasmic proteins of $E$. coli $\mathrm{DH} 5 \alpha(\mathrm{pB}$ luescript) (lane 1) and PM9 (lane 2). Protein size markers are given in KDa on the left. Results obtained with clone PM2 were the same as those obtained with PM9 and are not shown. a zymogram technique (Fig. 1b). The acid phosphatase produced by the two clones could be extracted by a chloroform treatment suitable for extraction of the periplasmic proteins from E. coli (Ferro-Luzzi Ames et al., 1984) (Fig. 1c) and the ratio of phosphatase activity between a periplasmic and a whole cell protein preparation was consistent with a location of this protein in the periplasmic space (data not shown).

Restriction mapping and cross-hybridization experiments performed using the insert carried by clone PM9 as a probe showed that the two clones carried overlapping DNA fragments (Fig. 2), which a Southern blot analysis confirmed to be derived from the $M$. morganii RS12 genome (data not shown).

The above results suggested that the Morganella gene encoding the minor phosphate-irrepressible acid phosphatase had been cloned. Definitive confirmation that the enzyme produced by PM2 and PM9 was actually encoded by the cloned DNA was obtained by comparison of the $\mathrm{NH}_{2}$ terminal sequencing data of the enzyme with the nucleotide sequence of the cloned DNA (see below).

\section{Characterization of the NapA enzyme}

Purification of the Morganella NapA enzyme from the culture supernatant of E. coli PM9 was achieved by means of two ion-exchange chromatography steps followed by a gel-filtration step (see Methods for details of the purification procedure). The two ion-exchange steps were able to remove most protein contaminants from the initial preparation (the NapA enzyme did not bind to either of the two matrices under the conditions adopted), while the final gel-filtration step allowed purification to homogeneity of the NapA protein, as judged by SDS-PAGE (Fig. 3a). The specific activity of the purified protein, assayed against $p \mathrm{NPP}$ at $\mathrm{pH} 6$, was $46 \cdot 2 \mathrm{U} \mathrm{mg}^{-1}$.

The $\mathrm{NH}_{2}$-terminal sequence of the NapA protein was determined as $\mathrm{NH}_{2}-\mathrm{KVYMPEKVSDGVTVAQLAEQ}$.

The molecular mass of the protein, estimated by gelfiltration chromatography, was approximately $105 \mathrm{kDa}$. This finding was confirmed by ultrafiltration experiments, which showed that the protein was completely retained by filters which excluded globular proteins of sizes larger than $100 \mathrm{kDa}$.

The NapA enzyme was completely denatured to the monomeric form following heating in the presence of $2 \%$ SDS (Fig. 3b). However, avoiding the heat treatment before loading the SDS-PAGE gel resulted in only partial denaturation of the protein, part of which migrated as an approximately $100 \mathrm{kDa}$ band (Fig. 3b). It was possible to vary the ratio between the $100 \mathrm{kDa}$ and the $27 \mathrm{kDa}$ forms by varying the duration of the exposure to SDS and/or the degree of heat treatment of the protein sample before loading the gel (data not shown). If heating was avoided and, at the same time, either the SDS concentration was lowered to $0.01 \%$, or $1 \%$ Triton X-100 was added, the protein migrated almost exclusively as a $100 \mathrm{kDa}$ band (Fig. 3b). Results of partially denaturing SDS-PAGE, which gave a molecular mass of approximately $100 \mathrm{kDa}$ 


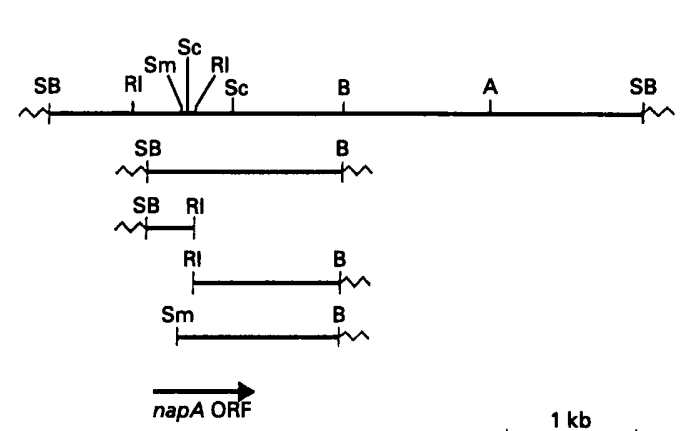

$\begin{array}{lc}\text { Clone/subclone } & \begin{array}{c}\text { NapA } \\ \text { production }\end{array} \\ \text { PPM2 } & + \\ \text { PPM9 } & + \\ \text { pPM9/03R } & - \\ \text { PPM9/12R } & - \\ \text { pPM9/135m } & -\end{array}$

Fig. 2. Restriction endonuclease map of the DNA inserts of the recombinant plasmids carried by clones $P M 2$ and $P M 9$ (respectively named pPM2 and pPM9) and subcloning strategy. SB, Sau3Al/BamHI junction; RI, EcoRI; Sm, Smal; Sc, Sacll; B, BamHI; A, Apal. Thick lines represent Morganella DNA while thin zigzag lines represent vector sequences. The location of the putative NapA ORF identified on the basis of sequencing data is shown below the map. Production of the NapA protein was assayed both by measuring pNPP-hydrolysing activity at $\mathrm{pH} 6$, and by SDS-PAGE analysis of periplasmic proteins of different subclones.

(a)

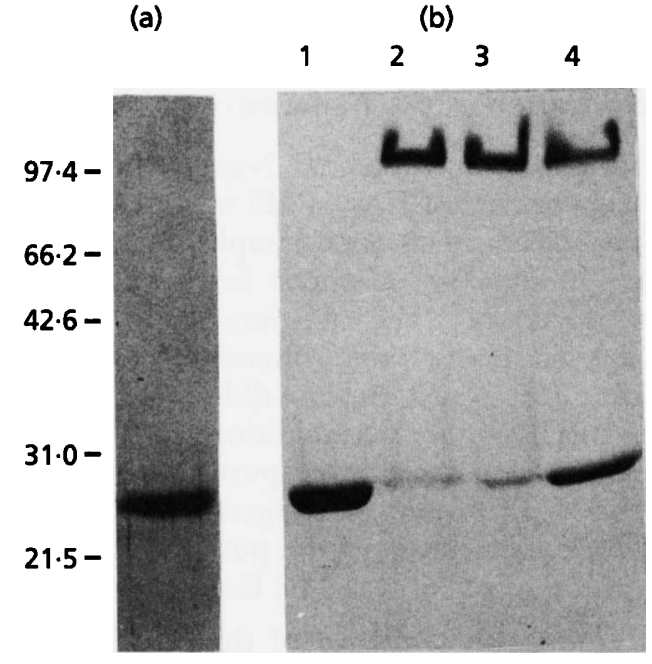

Fig. 3. SDS-PAGE analysis of the purified NapA protein. (a) Purified NapA protein (approximately $5 \mu \mathrm{g}$ ); the gel was stained with a silver staining technique (Heukeshoven \& Dernick, 1985) allowing a detection sensitivity of at least $5 \mathrm{ng}$ of protein per band. (b) Coomassie-blue-stained preparation of the purified NapA protein subjected to SDS-PAGE after different treatments before loading: the protein was mixed with Laemmli's sample buffer in the presence of $2 \%$ SDS and boiled for $5 \mathrm{~min}$ (lane 1), mixed with Laemmli's sample buffer in the presence of $2 \%$ SDS and $1 \%$ Triton X-100 and incubated at $25^{\circ} \mathrm{C}$ for $5 \mathrm{~min}$ (lane 2), mixed with Laemmli's sample buffer in the presence of $0.01 \%$ SDS and incubated at $25^{\circ} \mathrm{C}$ for $5 \mathrm{~min}$ (lane 3), or mixed with Laemmli's sample buffer in the presence of $2 \%$ SDS and incubated at $25^{\circ} \mathrm{C}$ for $5 \mathrm{~min}$ (lane 4). Protein size markers are given in $\mathrm{KDa}$ on the left.

for the partially denatured NapA protein, were consistent with gel-filtration and ultrafiltration data concerning the size of the native protein.

The purified protein preparation was used to analyse some of its functional properties. Using $p \mathrm{NPP}$ as substrate, the NapA enzyme showed a pH optimum around 6, retaining
Table 1. pNPP-hydrolysing activity of the NapA phosphatase at different $\mathrm{pH}$ values

All assays were performed using $0.3 \mu \mathrm{g}$ of the purified enzyme in a volume of $1 \mathrm{ml}$.

\begin{tabular}{|c|c|c|}
\hline pH & $\begin{array}{l}\text { pNP production } \\
\left(\mathrm{nmol} \mathrm{min}^{-1} \mathrm{ml}^{-1}\right)^{*}\end{array}$ & $\begin{array}{l}\text { Relative } \\
\text { activity }\end{array}$ \\
\hline 4 & $7 \cdot 86 \pm 0 \cdot 13$ & 0.60 \\
\hline $4 \cdot 5$ & $10 \cdot 22 \pm 0 \cdot 15$ & 0.78 \\
\hline 5 & $10 \cdot 74 \pm 0.15$ & 0.82 \\
\hline $5 \cdot 5$ & $11 \cdot 53 \pm 0.17$ & 0.88 \\
\hline 6 & $13 \cdot 10 \pm 0 \cdot 18$ & $1 \cdot 00$ \\
\hline $6 \cdot 5$ & $12 \cdot 45 \pm 0 \cdot 19$ & 0.95 \\
\hline 7 & $11 \cdot 40 \pm 0 \cdot 17$ & 0.87 \\
\hline 8 & $5 \cdot 11 \pm 0 \cdot 10$ & $0 \cdot 39$ \\
\hline 9 & $1 \cdot 70 \pm 0.05$ & $0 \cdot 13$ \\
\hline 10 & $0.39 \pm 0.04$ & 0.03 \\
\hline
\end{tabular}

* Mean value of three experiments $\pm S E$.

more than $50 \%$ of maximal activity in the $\mathrm{pH}$ range 4-7 (Table 1). The enzyme showed a broad substrate specificity which did not include diesters (Table 2). The activity of the enzyme was inhibited by EDTA, inorganic phosphate and $\mathrm{Ca}^{2+}$, stimulated by $\mathrm{Mg}^{2+}, \mathrm{Co}^{2+}$ and $\mathrm{Zn}^{2+}$, and apparently unaffected by fluoride and tartrate (Table 3). NapA also showed transphosphorylating activity from organic phosphoric acid esters to nucleosides and other compounds with free hydroxyl groups (Table 4). Results of these experiments also showed that the activity of NapA was inhibited by nucleosides and stimulated by high concentrations of ethanol and glycerol.

The functional properties of the NapA enzyme, as well as the sizes of the native protein and of its polypeptide component, are very similar to those of the $S$. typhimurium NapII enzyme (Uerkvitz, 1988; Uerkvitz \& Beck, 1981). 
Table 2. Relative activities of the NapA phosphatase toward various substrates

All assays were performed using $0.3 \mu \mathrm{g}$ of the purified enzyme in a volume of $1 \mathrm{ml}$.

\begin{tabular}{|c|c|c|}
\hline Substrate & $\begin{array}{c}P_{\mathrm{i}} \text { production } \\
\left(\mathrm{nmol} \mathrm{min}^{-1} \mathrm{ml}^{-1}\right)^{*}\end{array}$ & $\begin{array}{l}\text { Relative } \\
\text { activity }\end{array}$ \\
\hline $5^{\prime}$-AMP & $10 \cdot 37 \pm 0 \cdot 21$ & $1 \cdot 00$ \\
\hline $5^{\prime}$-UMP & $2 \cdot 90 \pm 0.08$ & $0 \cdot 28$ \\
\hline 3'-AMP & $12 \cdot 34 \pm 0 \cdot 23$ & $1 \cdot 19$ \\
\hline 3'-UMP & $6.95 \pm 0.14$ & 0.67 \\
\hline$p N P P$ & $12 \cdot 86 \pm 0.25$ & $1 \cdot 24$ \\
\hline PDP & $11 \cdot 82 \pm 0 \cdot 20$ & $1 \cdot 14$ \\
\hline G2P & $5 \cdot 08 \pm 0 \cdot 11$ & 0.49 \\
\hline Glucose 6-P & $2.07 \pm 0.06$ & 0.20 \\
\hline Ribose 5-P & $0.62 \pm 0.05$ & 0.06 \\
\hline $2^{\prime}: 3^{\prime}-$ Cyclic AMP & $<\overline{0} \cdot 1$ & $<0.01$ \\
\hline $2^{\prime}: 3^{\prime}$-Cyclic UMP & $<0 \cdot 1$ & $<0.01$ \\
\hline
\end{tabular}

* Mean value of three experiments $\pm \mathrm{sE}$.

Table 3. Effect of various substances on the pNPPhydrolysing activity of the NapA enzyme

All assays were performed using $0.3 \mu \mathrm{g}$ of the purified enzyme in a volume of $1 \mathrm{ml}$.

\begin{tabular}{|c|c|c|}
\hline $\begin{array}{l}\text { Substance } \\
(\mathrm{mM})\end{array}$ & $\begin{array}{l}p N P \text { production } \\
\left(\mathrm{nmol} \mathrm{min}^{-1} \mathrm{ml}^{-1}\right)^{*}\end{array}$ & $\begin{array}{l}\text { Relative } \\
\text { activity }\end{array}$ \\
\hline None & $12 \cdot 50 \pm 0 \cdot 19$ & 1.00 \\
\hline EDTA (1) & $1 \cdot 25 \pm 0 \cdot 05$ & $0 \cdot 10$ \\
\hline EDTA $(20)$ & $<\overline{0} \cdot 1$ & $<0.01$ \\
\hline$P_{i}(20)$ & $12 \cdot 75 \pm 0.18$ & 1.02 \\
\hline$P_{1}(50)$ & $10 \cdot 25 \pm 0 \cdot 16$ & $0 \cdot 82$ \\
\hline$P_{i}(100)$ & $7 \cdot 75 \pm 0 \cdot 14$ & 0.62 \\
\hline Tartrate (1) & $12 \cdot 88 \pm 0 \cdot 18$ & 1.03 \\
\hline Tartrate (10) & $12 \cdot 38 \pm 0 \cdot 19$ & 0.99 \\
\hline $\mathrm{F}^{-}(1)$ & $11 \cdot 88 \pm 0 \cdot 17$ & 0.95 \\
\hline $\mathrm{F}^{-}(10)$ & $11 \cdot 50 \pm 0 \cdot 18$ & 0.92 \\
\hline $\mathrm{Ca}^{2+}(1)$ & $1 \cdot 25 \pm 0.07$ & $0 \cdot 10$ \\
\hline $\mathrm{Mg}^{2+}(1)$ & $21.63 \pm 0.31$ & $1 \cdot 73$ \\
\hline $\mathrm{Co}^{2+}(1)$ & $30 \cdot 25 \pm 0.41$ & $2 \cdot 42$ \\
\hline $\mathrm{Zn}^{2+}(1)$ & $17 \cdot 25 \pm 0 \cdot 26$ & $1 \cdot 38$ \\
\hline
\end{tabular}

* Mean value of three experiments \pm SE.

\section{Structure of the napA gene and deduced amino acid sequence of the NapA protein}

The nucleotide sequence of the Morganella DNA insert of plasmid pPM9 was determined, and a computer analysis of possible coding regions allowed identification of a single ORF whose size was compatible with the results of SDS-PAGE analysis, and which was able to code for a polypeptide containing an amino acid sequence corresponding to the $\mathrm{NH}_{2}$-terminal sequence of the NapA
Table 4. Phosphotransferase activity of the NapA phosphatase in the presence of pNPP $(5 \mathrm{mM})$ as donor and various organic phosphate acceptors containing free hydroxyl groups

All assays were performed using $0 \cdot 15 \mu \mathrm{g}$ of the purified enzyme in a volume of $1 \mathrm{ml}$.

\begin{tabular}{|c|c|c|c|}
\hline \multirow[t]{2}{*}{ Acceptor (mM) } & \multicolumn{2}{|c|}{ 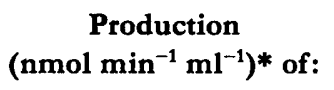 } & \multirow{2}{*}{$\begin{array}{c}\text { Phosphate } \\
\text { transfer } \\
(\%)\end{array}$} \\
\hline & $p \mathbf{N P}$ & $\mathbf{P}_{\mathbf{i}}$ & \\
\hline $\mathrm{H}_{2} \mathrm{O}$ & $5.95 \pm 0.12$ & $5.99 \pm 0.13$ & 0 \\
\hline Ethanol (200) & $9 \cdot 70 \pm 0 \cdot 15$ & $7 \cdot 08 \pm 0 \cdot 15$ & 27 \\
\hline Ethanol (1000) & $18 \cdot 35 \pm 0.29$ & $3 \cdot 90 \pm 0 \cdot 10$ & 79 \\
\hline Ethanol (2000) & $17 \cdot 55 \pm 0 \cdot 27$ & $1.90 \pm 0.08$ & 89 \\
\hline Glycerol (200) & $7 \cdot 95 \pm 0 \cdot 14$ & $7 \cdot 10 \pm 0 \cdot 16$ & 11 \\
\hline Glycerol (1000) & $10 \cdot 30 \pm 0 \cdot 16$ & $2.95 \pm 0.09$ & 71 \\
\hline Adenosine $(0 \cdot 1)$ & $2 \cdot 95 \pm 0.08$ & $2 \cdot 15 \pm 0.07$ & 27 \\
\hline $\begin{array}{l}2^{\prime} \text {-Deoxyadenosine } \\
(0 \cdot 1)\end{array}$ & $3 \cdot 65 \pm 0 \cdot 11$ & $2 \cdot 80 \pm 0.09$ & 23 \\
\hline Cytidine $(0 \cdot 1)$ & $4 \cdot 10 \pm 0 \cdot 10$ & $3 \cdot 85 \pm 0 \cdot 11$ & 6 \\
\hline $2^{\prime}$-Deoxycitidine $(0 \cdot 1)$ & $3 \cdot 30 \pm 0 \cdot 10$ & $2.50 \pm 0.08$ & 24 \\
\hline Uridine $(0 \cdot 1)$ & $2.20 \pm 0.07$ & $1.70 \pm 0.06$ & 22 \\
\hline $2^{\prime}$-Deoxyuridine $(0 \cdot 1)$ & $2 \cdot 20 \pm 0 \cdot 08$ & $1.55 \pm 0.06$ & 29 \\
\hline
\end{tabular}

* Mean value of three experiments $\pm \mathrm{SE}$.

protein (Fig. 4). Since the insert of pPM9 terminated at a Sau3AI site located a short distance upstream of the start codon (Fig. 4), part of the insert of pPM2 was also sequenced to determine the structure of the $5^{\prime}$-flanking region of the nap $A$ gene.

The nap $A$ ORF has the potential to code for a polypeptide of 236 amino acids with a predicted molecular mass of $26686 \mathrm{Da}$. The deduced amino acid sequence of the $\mathrm{NH}_{2}-$ terminal region of the polypeptide showed features resembling those of prokaryotic signal sequences for protein export to the periplasmic space (Oliver, 1985) and, on the basis of $\mathrm{NH}_{2}$-terminal sequencing data, it actually appeared to function as a signal sequence which is cleaved by signal peptidase after the alanine residue at position 23 . A putative ribosome-binding site resembling those of $E$. coli is located upstream of the start codon.

All E. coli strains harbouring recombinant plasmids which included the nap $A$ ORF and flanking sequences showed strong $p$ NPP-hydrolysing activity and were able to produce the NapA protein. On the other hand, strains harbouring recombinant plasmids which contained only a portion of the nap $A$ ORF showed $p$ NPP-hydrolysing activity comparable to that of $E$. coli $\mathrm{DH} 5 \alpha$ (pBluescript) and were not able to produce the NapA protein (Fig. 2). These data were in agreement with the hypothesis that the above ORF actually encoded the NapA protein.

The presence of a similar genomic region including the nap $A$ ORF was also analysed in the $M$. morganii strain ATCC $25830^{\mathrm{T}}$ by means of PCR using primers MMNAP- 
MMNAP-7f

141 GAATTCAGAACAATCATGCGGCTGTCAGCCGGTATAAAGCGGGGGGATTCCICACCGTG -81 TGATCTGAATAACGTTAATATGAAACCGGAATGGTTAGATTCTCACTCCGCGTGATCGAC -21 ACAGAAAATTAAGgATATACAATGCGTAAACTGACCCTCACCCTGAGTGCCCTGGCACTC 40 GCTCTGAGCCTCAACAGTGTGGCTGATGCCAAAGTGTACATGCCGGAAAAGTCAGTGAC $\begin{array}{llllllllllllllllllll}A & L & S & L & N & S & V & A & D & A & K & V & Y & M & P & E & K & V & S & D\end{array}$ 100 GGCGTGACCGTTGCTCAGCTGGCAGAACAGCATGCCATTCACTGGATTTCGGTTGAACAG

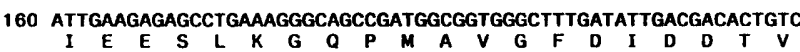
220 TTATTCTCAAGCCCGGGCTTTTACCGCGGCAAACTGGAATACTCCCCGAACGACTACAGT $\begin{array}{llllllllllllllllllll}L & F & S & S & P & G & F & Y & R & G & K & L & E & Y & S & P & N & D & Y & S\end{array}$ 280 TATCTGAAAAACCCGGAATTCTGGGAAAAAATGAATAATGAGTGGGATAAATTCAGTATG $Y$ L $K$ N $P$ E F W E K M N N E W D K F S M 340 CCGAAAAAATCCGGTATGGAACTGGTTCAGATGCACCTGAAACGTGGTGATACCGTTTAT $P K$ K S G M E L V O M H L K R G D T V $Y$ 400 TTCATCACCGGGGCAGCAAAACCAAAACAGAAACGGTCACCAAATATGTTCAGGAAGGG $\begin{array}{llllllllllllllllllll}F & I & T & G & R & S & K & T & K & T & E & T & V & T & K & Y & V & Q & E & G\end{array}$ 460 CTGCGTATCCCGGCAGATAAAATGAACCCGGTTATTTYTGCCGGTGATGAGGAAGGGCAG

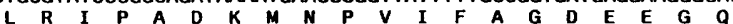
520 AATAATAAAGTCAGCTGGATGCGTGATCACAAACTGAAAATITATTACGGTGATGCGGAT N N K V S W M R D H K L K I Y Y G G D A 580 GCCGATATTGCCGCAGCACGGGAACTGAATATCCGCGGTATCCGGGTATTACGCGCTTCG A D I A A A R E L N I R G I R V L R A S 640 AACTCCTCGTATCAGCCGCTGCCGAAAGCCGGTCAGTTCGGCGAGGAAGTGGITATTAAT $\begin{array}{llllllllllllllllllll}N & S & S & Y & Q & P & L & P & K & A & G & Q & F & G & E & E & V & V & I & N\end{array}$

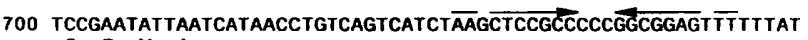
$S$ E Y *

MMNAP-4r

760 TTGTGTTGTTTATTGTCCGGCGCAGATTTGTTIATCCGGGAGAAAAGCAGAGATGAGA 820 TGTATTTCATCGCACTCAATACATGCGTTTGCGTAATTAGTGCAGTGTATTCCTCTTAAA 880 AAGATGTAITTGCGCCTTITTITIACGATTITTTCGTTATCCTATITTCAATTATTCTCT 940 gaCAGgTAaAatcagcaggGaAgtCattTTAaA

Fig. 4. Nucleotide sequence of the napA ORF and flanking regions. Number 1 represents the first base of the start codon of the napA ORF. The putative ribosome-binding site is underlined. The two convergent arrows indicate the downstream inverted repeat possibly functioning as a transcriptional terminator. The deduced amino acid sequence of the NapA protein is given under the nucleotide sequence. The signal sequence of the NapA protein is underlined. The PCR primers MMNAP-7f and MMNAP-4r used for PCR analysis of the napA locus in $M$. morganii ATCC $25830^{\top}$ are also indicated.

$7 f$ and MMNAP-4r (Fig. 4) and genomic DNA extracted from this strain as the template. An amplification product of the expected size ( $947 \mathrm{bp}$ ), which showed a restriction map (with EcoRI, SmaI and SacII) consistent with the sequencing data, was obtained from the $M$. morganii type strain (data not shown).

The $\mathrm{G}+\mathrm{C}$ content of the sequenced region ( $46 \mathrm{~mol} \%$ ) and of the nap $A$ ORF ( $49 \mathrm{~mol} \%$ ), as well as at the third position of codons $(56 \mathrm{~mol} \%)$, are consistent with the value reported ( $50 \mathrm{~mol} \%$ ) for the $M$. morganii genome (Falkow et al., 1962).

\section{Identification of putative NapA homologues on the basis of sequence comparison}

Comparison of the deduced amino acid sequence of the NapA protein with those of other sequenced bacterial periplasmic phosphatases including the E. coli PhoA (Chang et al., 1986), UshA (Burns \& Beacham, 1986a),

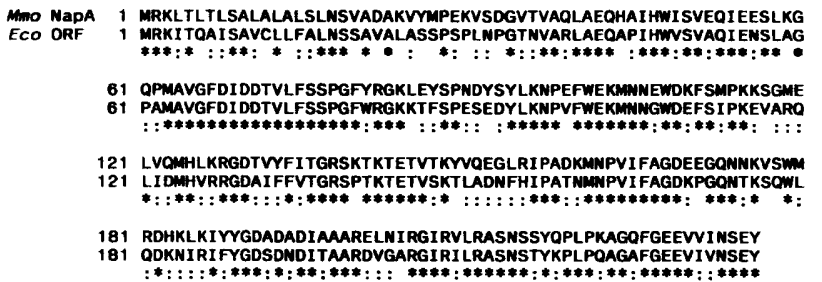

Mmo NapA 1 MRKLTLTLSALALALSLNSVADAKUMMPEKVSOGVTVAQLAEOHAI HWISVEQIEESLKG MRKVTLTLSAIALALSLNGAAMAKVHAPEVVSCG-DX--X

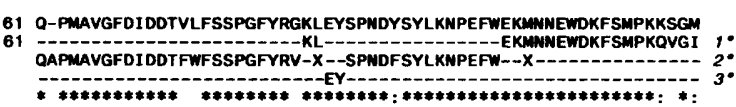

OO ELVOWHLKRGDTWFITGRSKTKTET-VTKYVOEGLRIP 121 DLVOHLKRGDTVYFITGRTOTKTETCVTKYVOEGLNIP

Fig. 5. Comparison of the deduced amino acid sequences of the NapA phosphatase of $M$. morganii (Mmo NapA) with those of the hypothetical proteins of $E$. coli (Eco ORF; EMBL accession number Z26592) and P. mirabilis (Pmi ORF; Charles et al., 1985; EMBL accession number M11587) showing sequence homology to NapA. Numbers on the left correspond to the residue numbers of the proteins. Identical residues are indicated by an asterisk; conservative amino acid substitutions are indicated by a colon. In the comparison between the NapA enzyme and the $P$. mirabilis hypothetical protein, homology is followed through different reading frames (indicated as $1^{\circ}, 2^{\circ}$ and $3^{\circ}$, respectively) and frameshifts introduced to follow homology are indicated; $X$ indicates a stop codon.

CpdB (Liu et al., 1986), Agp (Pradel et al., 1990) and AppA (Dassa et al., 1990) enzymes, and the four known class A acid phosphatases (Groisman et al., 1992; Pond et al., 1989; Thaller et al., 1994; M. L. Riccio and others, unpublished, EMBL accession number X64820), did not reveal any significant homology.

When the deduced amino acid sequence of the $M$. morganii NapA enzyme was compared with all sequences present in the EMBL database (release 37) by means of the TFASTA program (Pearson, 1990), a high degree of homology was found with two hypothetical proteins of unknown function encoded by sequenced regions of the E. coli and Proteus mirabilis genomes respectively. The hypothetical E. coli NapA homologue is encoded by an ORF located at $92 \mathrm{~min}$, in the $\operatorname{tyr} B-u v r A$ intergenic region (EMBL accession number Z26592), and shows an overall degree of homology of $60.6 \%$ (rising to $90.7 \%$ when conservative amino acid substitutions are allowed for) with the Morganella NapA enzyme (Fig. 5). Interestingly, the opposite strand of this ORF entirely encompasses another ORF encoding a DNA-binding protein specific for the $E$. coli origin of replication (cited in EMBL entry Z26592). With regard to the $P$. mirabilis NapA homologue, it is apparently encoded by an ORF located $0.4 \mathrm{~kb}$ upstream of the chromosomal cat gene which is involved in chloramphenicol resistance (Charles et al., 1985). In this case, however, only part of the sequence is available (corresponding to amino acids 1-157 of the Morganella NapA protein) and the ORF encoding the NapA homologue is 
prematurely interrupted by a termination codon (Fig. 5). However, since the homology can be followed in alternative reading frames (Fig. 5), and since a NapA-like phosphatase is actually present in P. mirabilis (M. C. Thaller and others, unpublished), it seems more likely that the interruptions in the $P$. mirabilis ORF are due to sequencing errors than to actual mutations that led to a silencing event. Considering the alignment that can be obtained after frameshifts have been introduced to follow homology, the P. mirabilis NapA homologue shows, in the sequenced region, an overall degree of homology of $79.9 \%$ (rising to $95.6 \%$ when conservative amino acid substitutions are allowed for).

\section{DISCUSSION}

Phosphatase activities of enteric bacteria have been studied from several viewpoints, but current knowledge on these enzymes is still incomplete.

With regard to periplasmic acid phosphatases, several different enzymes have been described and characterized at the sequence level, and different molecular classes of these enzymes can be recognized on the basis of sequence data and functional properties. These include: (a) the class A acid phosphatases, which are EDTA-resistant nonspecific acid phosphatases composed of low molecular mass polypeptides $(\sim 25-27 \mathrm{kDa})$, thus far described in S. typhimurium (Groisman et al., 1992; Weppelman et al., 1977), M. morganii (Thaller et al., 1994) and P. stuartii (M. L. Riccio and others, unpublished, EMBL accession number X64820); (b) the Agp-AppA family of enzymes described in $E$. coli, which includes two enzymes with somewhat different properties [an acid glucose phosphatase (Agp) and an acid phosphatase with a very low $\mathrm{pH}$ optimum (AppA)] which are homologous at the sequence level and are probably derived from the same ancestor gene (Dassa et al., 1990); (c) the periplasmic UDP-sugar hydrolases, thus far characterized and sequenced in E. coli and S. typhimurium (Burns \& Beacham, 1986a, b) (in the latter species the gene is silent), but probably present in several enteric bacteria (Neu, 1968); (d) the cyclic phosphodiesterases, thus far sequenced in $E$. coli (Liu et al., 1986), but apparently present in several enteric bacteria (Neu, 1968).

Characterization and sequencing of the $M$. morganii NapA acid phosphatase, previously identified as a minor phosphate-irrepressible acid phosphatase (Thaller et al., 1994), enabled its recognition as a new molecular species of bacterial periplasmic acid phosphatase. Since an enzyme with similar properties has been described in $S$. typhimurium (Uerkvitz, 1988; Uerkvitz \& Beck, 1981), it is reasonable to hypothesize that this enzyme represents a NapA homologue produced by $S$. typhimurium. Moreover, genes homologous to nap $A$ are present in the E. coli and $P$. mirabilis genomes and, although their products have not been characterized, we have recently described in $E$. coli a nonspecific acid phosphatase composed of a $27 \mathrm{kDa}$ polypeptide component (Rossolini et al., 1994) which could correspond to the product of the nap $A$ homologue found in this species, and we have also found a NapA-like protein in $P$. mirabilis (M. C. Thaller and others, unpublished). The Morganella NapA enzyme, therefore, appears to be a member of a family of conserved enzymes which we propose designating class $\mathrm{B}$ bacterial acid phosphatases, and which could be widespread among enteric bacteria. We are currently investigating the presence of NapA homologues in other enteric bacteria, and preliminary results indicate a widespread distribution of such enzymes among members of this family (M. C. Thaller and others, unpublished).

The class B bacterial acid phosphatases thus far characterized (i.e. the Morganella NapA and the Salmonella NapII enzymes) are nonspecific acid phosphatases composed of low molecular mass polypeptides similar to class A enzymes, but unlike the latter they apparently require a metal cofactor for activity and are more susceptible to phosphate inhibition. Interestingly, these enzymes are also endowed with phosphotransferase activity, a property that could be relevant in cell physiology, especially for an enzyme located in the periplasmic space. The physiological role of these enzymes remains to be established. In S. typhimurium, the NapII enzyme has been considered as the major periplasmic 5'-nucleotidase (Uerkvitz \& Beck, 1981). It would be interesting to confirm a similar role in other bacterial species and to investigate whether other functions are dependent on these class B enzymes.

\section{ACKNOWLEDGEMENTS}

This work was supported in part by grant nos 92.01195. PF70 and 93.01030. PF70 from the Italian National Research Council (CNR), targeted project 'Biotecnologie e Biostrumentazione', and no. 92.02779.CT04 from the CNR. We should like to thank Giuseppe Satta for helpful suggestions and discussions and Annalisa Santucci for $\mathrm{NH}_{2}$-terminal sequencing of the NapA enzyme. Thanks are also due to Francesco Lissi and Elena Sestini for their skilful editorial assistance.

\section{REFERENCES}

Ames, B. N. (1966). Assay of inorganic phosphate, total phosphate and phosphatases. Methods Enzymol 8, 115-118.

Beacham, I. R. (1979). Periplasmic enzymes in Gram-negative bacteria. Int J Biochem 10, 877-883.

Burns, D. M. \& Beacham, I. R. (1986a). Nucleotide sequence and transcriptional analysis of the $E$. coli ush $A$ gene, encoding periplasmic UDP-sugar hydrolase ( 5 '-nucleotidase): regulation of the $u s h A$ gene, and the signal sequence of its encoded protein product. Nucleic Acids Res 14, 4325-4342.

Burns, D. M. \& Beacham, I. M. (1986b). Identification and sequence analysis of a silent gene (ush $A^{0}$ ) in Salmonella typhimurium. J Mol Biol 192, 163-175.

Chang, C. N., Kuang, W.-J. \& Chen, E. Y. (1986). Nucleotide sequence of the alkaline phosphatase gene of Escherichia coli. Gene 44, 121-125.

Charles, I. G., Keyte, J. W. \& Shaw, W. V. (1985). Nucleotide sequence analysis of the cat gene of Proteus mirabilis: comparison with the type I (Tn9) cat gene. J Bacteriol 164, 123-129.

Cocks, G. T. \& Wilson, A. C. (1972). Enzyme evolution in the Enterobacteriaceae. J Bacteriol 110, 793-802. 
Dassa, J., Marck, C. \& Boquet, P. L. (1990). The complete nucleotide sequence of the Escberichia coli gene $a p p A$ reveals significant homology between $\mathrm{pH} 2.5$ acid phosphatase and glucose-1-phosphatase. J Bacteriol 172, 5497-5500.

Devereux, J., Haeberli, P. \& Smithies, O. (1984). A comprehensive set of sequence analysis programs for the VAX. Nucleic Acids Res 12, 387-395.

Dvorak, H. F., Brockman, R. W. \& Heppel, L. A. (1967). Purification and properties of two acid phosphatase fractions isolated from osmotic shock fluid of Escherichia coli. Biocbemistry 6, 1743-1751.

Edwards, C. J., Innes, D. J., Burns, D. M. \& Beacham, I. R. (1993). UDP-sugar hydrolase isozymes in Salmonella enterica and Escherichia coli: silent alleles of ush $A$ in related strains of Group I Salmonella isolates, and of ushB in wild-type and $\mathrm{K} 12$ strains of E. coli, indicate recent and early silencing events, respectively. FEMS Microbiol Lett 114, 293-298.

Falkow, S., Ryman, I. R. \& Washington, O. (1962). Deoxyribonucleic acid base composition of Proteus and Providence organisms. J Bacteriol 83, 1318-1321.

Ferro-Luzzi Ames, G., Prody, C. \& Kustu, S. (1984). Simple, rapid, and quantitative release of periplasmic proteins by chloroform. J Bacteriol 160, 1181-1183.

Groisman, E. A., Saier, M. H., Jr \& Ochman, H. (1992). Horizontal transfer of a phosphatase gene as evidence for mosaic structure of the Salmonella genome. EMBO J 11, 1309-1316.

Heukeshoven, J. \& Dernick, R. (1985). Simplified method for silver staining of proteins in polyacrylamide gels and the mechanism of silver staining. Electropboresis 6, 103-112.

Kier, L. D., Weppelman, R. \& Ames, B. N. (1977). Resolution and purification of three periplasmic phosphatases of Salmonella typhimurium. J Bacteriol 130, 399-410.

Laemmli, U. K. (1970). Cleavage of structural proteins during the assembly of the head of bacteriophage T4. Nature 227, 680-685.

Liu, J., Burns, D. M. \& Beacham, I. R. (1986). Isolation and sequence analysis of the gene $(c p d B)$ encoding periplasmic $2^{\prime}, 3^{\prime}$-cyclic phosphodiesterase. J Bacteriol 165, 1002-1010.

Matsudaira, P. (1987). Sequence from picomole quantities of proteins electroblotted onto polyvinylidene difluoride membranes. $J$ Biol Chem 262, 10035-10038.

Neu, H. C. (1968). The 5'-nucleotidases and cyclic phosphodiesterases ( $3^{\prime}$-nucleotidases) of the Enterobacteriaceae. J Bacteriol 95 , 1732-1737.

Oliver, D. (1985). Protein secretion in Escherichia coli. Annu Rev Micrabiol 39, 615-618.
Pearson, W. R. (1990). Rapid and sensitive sequence comparison with FASTP and FASTA. Methods Enzymol 183, 63-98.

Pompei, R., Cornaglia, G., Ingianni, A. \& Satta, G. (1990). Use of a novel phosphatase test for simplified identification of species of the tribe Proteae. J Clin Microbiol 28, 1214-1218.

Pompei, R., Ingianni, A., Foddis, G., Di Pietro, G. \& Satta, G. (1993). Patterns of phosphatase activity among enterobacterial species. Int J Syst Bacteriol 43, 174-178.

Pond, J. L., Eddy, C. K., Mackenzie, K. F., Conway, T., Borecky, D. J. \& Ingram, L. O. (1989). Cloning, sequencing, and characterization of the principal acid phosphatase, the $p h o C^{+}$product, from Zymomonas mobilis. J Bacteriol 171, 767-774.

Pradel, E., Marck, C. \& Boquet, P. L. (1990). Nucleotide sequence and transcriptional analysis of the Escherichia coli agp gene encoding periplasmic acid glucose-1-phosphatase. J Bacteriol 172, 802-807.

Reiland, J. (1971). Gel filtration. Methods Enzymol 22, 287-321.

Rossolini, G. M., Thaller, M. C., Pezzi, R. \& Satta, G. (1994). Identification of an Escherichia coli periplasmic acid phosphatase containing a $27 \mathrm{kDa}$-polypeptide component. FEMS Microbiol Lett 118, 167-174.

Sambrook, J., Fritsch, E. F. \& Maniatis, T. (1989). Molecular Cloning: a Laboratory Manual, 2nd edn. Cold Spring Harbor, NY: Cold Spring Harbor Laboratory.

Sanger, F., Nicklen, S. \& Coulson, A. R. (1977). DNA sequencing with chain-terminating inhibitors. Proc Natl Acad Sci US A 74, 5463-5467.

Thaller, M. C., Berlutti, F., Schippa, S., Lombardi, G. \& Rossolini, G. M. (1994). Characterization and sequence of $\mathrm{PhoC}$, the principal phosphate-irrepressible acid phosphatase of Morganella morganii. Microbiology 140, 1341-1350.

Uerkvitz, W. (1988). Periplasmic nonspecific acid phosphatase II from Salmonella typhimurium LT2. J Biol Chem 263, 15823-15830.

Uerkvitz, W. \& Beck, C. F. (1981). Periplasmic phosphatases in Salmonella typhimurium LT2. A biochemical, physiological, and partial genetic analysis of three nucleoside monophosphate dephosphorylating enzymes. $J$ Biol Chem 256, 382-389.

Weppelman, R., Kier, L. D. \& Ames, B. N. (1977). Properties of two phosphatases and a cyclic phosphodiesterase of Salmonella typhimurium. J Bacteriol 130, 411-419.

Received 22 April 1994; revised 9 August 1994; accepted 21 September 1994. 